\title{
NEW SPECIES OF NOCTUIDS FOR 1904. NO. 2.
}

\author{
BY JOHN B. SMITH, SC. D., NEW BRUNSWICK, N. J.
}

\author{
Xylophasia unita, n. sp.
}

Ground color dull ashen gray, the maculation well defined and black. Head mottled, front with alternate white and blackish lines. Collar pale at base; a black transverse line above the middle, then smoky to a gray tip. Patagia black edged and with an inner submarginal line. Disc of thorax powdery. Primaries with a black longitudinal line at base, extending almost to the $t$. a. line, somewhat diffuse inferiorly. There is also a blackish shading along inner margin. Basal line geminate, blackish, broken. T. a. line geminate, outer part 2 little broader and blacker, even throughout; a little outcurved in the interspaces, outcurved over cell and a little incurved below; inner line blackish, lunulate, best marked below vein 2 ; outer line even, slender, smoky; included space gray. S. t. line narrow, whitish, forming an obvious $\mathrm{W}$, preceded by sagittate black dashes at the middle and followed by a smoky shading. There is a series of small black terminal lunules. The median shade is from costa, outwardly oblique, darkening the space between the ordinary spots, inwardly angled below the reniform and running close to the t. p. line. A black bar connects the median lines just above vein 1. Claviform moderate, narrowly outlined in black, smoky. Orbicular large, oval, oblique, not well defined, gray. Reniform moderate in size, kidney-shaped, gray, without definite outline. Secondaries dull whitish with a faint yellowish tinge, becoming smoky outwardly, fringes whitish; a narrow median line. Beneath, primaries smoky gray, even, with a partial outer line; secondaries whitish, powdery, with a smoky discal lunule and a narrow, well marked extra median line.

Expands 1.56 inches $=39 \mathrm{~mm}$.

Habitat:-Calgary, Alberta, Head of Pine Creek, June 26 ; F. H. Wolley Dod.

One female, in good condition. The species resembles and is allied to cinefacta; but differs in the uniform bluish ash gray, the even black bar connecting the median lines and in the clearer better defined markings.

I have another female example from Corvallis, Oregon, which I refer here with considerable doubt. It may come within the range of variation; but more material is needed for positive decision.

\section{Xylophasia enigra, n. sp.}

Ground color a deep smoky brown, without contrasting maculation of any kind. Head without maculation. Collar with an obscure black median line. Thorax heavily built, restiture thick, an admixture of gray scales along the margins of the patagia. Abdominal tuftings well marked. Primaries with all the markings just traceable: the basal and median lines geminate a little darker, included space a little gray. S. t. line a little paler than the ground, forms a very small $\mathrm{W}$, and is variably emphasized by preceding and tollowing shades. There is an obscure, difiuse median shade, oblique from the costa between the ordinary spots then close to the t. p. line, darkening a little the outer portion of the median 
space. There is a series of black terminal lunules, followed by a very narrow pale line at base of the otherwise dark fringes. The latter are also narrowly cut with pale and a little notched at the outer margin. Claviform small, concolorous, barely outlined by darker scales. Ordinary spots obscure, not defined, more or less paler marked, of moderate size. The orbicular is oblique, narrow ovate. Reniform upright, a little constricted centrally. Secondaries smoky yellowish, darker outwardly, with a dark discal lunule and with yellowish fringes. Beneath whitish, powdery ; primaries more smoky on disc, with a paler terminal space, a discal spot, an extra-median and a s. t. dusky line; secondaries with a small discal spot, a well defined extra median line and a diffiuse sub-terminal shade.

Expands $1.36-1.50$ inches $=3+-37 \mathrm{~mm}$.

Habitat: Calgary, Alberta, Head of Pine Creek, July 3 and 7 ; F. H. Wolley Dod.

Three good males. This is one of those obscure species that have no positive characters and depend for their standing upon the absence of any that distinguish others. It is a little like fumosa; but has entire secondaries. The absence of black in the basal space excludes it from ferens which it otherwise resembles in size and general habitus.

\section{Xylophasia rorulenta, n. sp.}

Allied to suffusca in general appearance and heretofore confused with it. Mr. Dod has sent me a series for examination and after including my own examples I have separated out as suffusca those examples in which the ground is of an even lilac gray, the reddish suffusion is uniform, and neither the ordinary spots nor the terminal space contrasts strongly.

In the new species either the reniform or terminal space, or both, contrast strongly, and are violet or lilac gray. The s. t. line is more sharply defined, the preceding marks blackish and more contrasting as well as more numerous. The lower half of the wing tends to a gray which is best marked on the inner margin. The upper half of the wing is reddish, pulverulent and is darkest on the costa. Altogether this is a more vivid species.

Habitat:-Calgary, Alberta, June and July; Winnipeg, Manitoba; Denver, Colorado, in May; New York without date or specific locality.

Ten good examples equally divided as to sex are before me, and twelve of suffusca have been used in the comparison.

\section{Cleoceris discolor n. sp.}

Ground color a somewhat intense clay yellow, marked with black and gray so as to leave a blotchy appearance. Head clothed with a mixture of black and white hair and scales, giving it a gray appearance; an obscure, whitish interantennal line. Collar yellow at base, upper half mottled with black and white. Thoracic disc and center of patagia gray, mottled with yellow scales. Abdomen paler yellow. Primaries with the median lines obscured, yet traceable; t. a. nearly upright : t. p. squarely and only a little exserted over the cell, and a little incurved below. Basal space yellow, outer half blackish except along the inner margin and just below the median vein, where the yellow shade extends to the $t$. a. line and a little beyond. Median space black except along costa where it is yellow mottled, along the t. a. line where it is indented as already stated, and except for the ordinary spots, which are discolored. The orbicular is round or nearly so, with a few dusky scales in center. Reniform oblong, upright, with a dusky central line. The s.t. space is black on the costa; but the 
black narrows toward t. p. line, leaving the space yellow below the middle of the wing. S. $t$. line broken, black, a little ditiuse, somewhat irregular. Terminal space outwardly powdered with black. A series of black terminal lunules. Secondaries whitish at base, with a narrow, dusky, extramedian line, a smoky outer border with a paler suhmarginal line, and whitish fringes. Beneath, a pale lustrous gray; secondaries uniform; primaries with a paler terminal space and a little mottling on the disc.

Expands 3.25 inches $=31 \mathrm{~mm}$.

Habitat: -Taos, New Mexico, August 2oth.

One female, in good condition. It is more than probable that this will be found to be a distinctly variable species and the proportion of the yellow and black may be decidedly incon. stant. It is likely, however, that the discolored ordinary spots form a constant feature and in this may be found the obvious distinction from the other described species.

\section{Pleroma cinerea n. sp.}

Ground color a very light ashen gray, maculation smoky brown and not contrasting. Head a little paler, sides of the palpi and a little interantennal tuft smoky. Collar with a blackish median line surmounted by a whitish shading. Disc of the thorax smoky as are also the loose basal tutts on the abdomen. Primaries without ordinary spots, the median lines distinct on costa only. T. a. line single, broad, diffuse, outwardly oblique, reaching the median vein and then lost. T. p. line geminate, the two parts well separated, equaily distinct, outwardly oblique, reaching the subcosta only, the inner line there lost. The outer line is broken there, but becomes visible again as a smoky line which forms the inner border to a smoky shading which starts from the apex and extends obliquely inward to the middle of the submedian interspace. At that point a blackish streak crosses the line, limits the shade and reaches the $s$. $t$. line. The $s . t$. line is indicated by a series of interspatial black marks and streaks, more or less obviously bordered by a whitish area, the most prominent of which is above the anal angle. The fringes are a little wavy, gray, with a broad white interline. Secondaries smoky yellow, more whitish at base, fringes whitish. Beneath, primaries smoky, with an outer line indicated on costa: secondaries more whitish, powdery, with a brownish extra median line and a small discal spot.

Expands 1.40 inches $=3.5 \mathrm{~mm}$.

Habitat : - Corvallis, Oregon, at light, Sept. II ; Washburn.

One male, in fair condition. The species is obviously distinct from those previously described by the rery oblique costal indication of median lines and by the oblique dusky shading which extends from the outer third of the submedian interspace to the apex.

\section{Xylina fletcheri $n$. sp.}

Ground color deep blue gray, a little powdery. Front with an obscure line; collar with a slender, black median line; a blackish line at the base of the wings. Aldomen sinoky with a slightly reddish tinge, the lateral tuftings distinct. Primaries with costal region slightly paler at base, the veins narrowly black dotted except .io. $\mathrm{x}$, which is rather obviously blackish. A slender black basal streak which exiends to the end of a long outward tooth of the t. a. line. This t. a. line is marked on the costa, and is only fragmentarily traceable afterward. It makes a long inward tooth in the cell, a very long outward tooth in the sub- 
median interspace and seems to reach the inner margin on the median shade. T. p. line faintly traceable in one example as a narrow, strongly crenulate line. The median shade darkens the space between the ordinary spots, runs from above the orbicular to base of reniform, thence to the middle of the hind margin. It is obscure, ditiuse and tends to obsolescence. S. t. line is a series of smoky sagittate spots which tend to run together and do not reach the costa. Orbicular rather small, ovate, uprigint or a little oblique, neatly black ringed, complete within the cell; but in two examples there is a supplementary spot faintly indicated. Reniform upright, broad, a little constricted centrally, lower angles tending to extend, outlined by black scales, a few brown scales in center. Secondaries lustrous, smoky, with a reddish tinge toward base, a vague dusky discal spot and reddish fringes. Beneath, primaries smoky, with a powdery paler terminal space; secondaries reddish gray, powdery, with a distinct blackish discal spot and a smoky extra median line which tends to obsolescence.

Expands $1.70-1.90$ inches $=43-48 \mathrm{~mm}$.

Habitat: Ottawa, Ontario, October $3-7$; Dr. J. Fletcher.

One male and four females: all good specimens. Resembles incilla in appearance and general characters and with it belongs to the georgii series. As compared with ancilla this species is more even in color, has much smaller spots and has traceable median lines, at least the $t$. a. being marked in all cases. The general pattern is the same.

\section{Xylina ancilla, n. sp.}

Ground color dark bluish gray, powdery. Head with a black frontal line; basal segments of antennae scaled with white; collar with a narrow black median line; patagia with a black line at base of wings. Primaries rery uniform in color, the veins black marked, though not prominently so, costal half of basal space the palest part of the wing. There is a narrow black basal streak in the submedian interspace. An obscure dusky shade angles un this line near base, extending outwardly to costa and to the inner margin, the upper portion forming the limit of the basal paler area. The median lines are lost. A diffuse median shade which tends to obsolescence starts from costa above orbicular, angles outward to the base of reniform, then inward to the middle of inner margin. A slightly irregular series of small sagittate black spots indicates the s. t. line. A series of obscure dusky terminal lunules. Claviform wanting. Orbicular large, irregularly oval, oblique, with an appendix below the median vein, concolorous, more or less distinctly outlined by black scales. Reniform large, broad, upright, a little dilated inferiorly where it is darkened by the median shade and relieved by a few brown scales - the only color patch on the wing. Secondaries smoky, a little paler at base. lustrous, with a darker discal lunule and whitish fringes. Beneath, primaries ranging from reddish gray to dark smoky, the paler examples with a dark discal spot. Secondaries reddish gray, powdery, with a conspicuous black discal spot, and an extra median, somewhat wavy dark line.

Expands $1.50-1.75$ inches $=37-+3 \mathrm{~mm}$.

Habitat: Calgary, Alberta, Head of Pine Creek, September 18, Mr. Dod; Cartwright, Manitoba, October 6, Mr. Heath; Wellington, British Columbia, September 7, Mr. Bryant.

One male and two females, in good condition. The species is allied to oregonensis Harv., but is of a very dark blue gray, with much less contrast, and inconspicuous maculation. The scant material indicates a considerable range of variation and that the more uniform examples may be confused with well marked georgii or holocinerea. 


\section{Xylina vertina, n. sp.}

Ashen gray with a bluish tint, more or less powdery. Head with smoky and black powderings, with a black frontal line. Collar a little brownish at base, to a narrow black median line, above which is a distinct white edging. Patagia with a black line at base of primaries. Abdomen a little rufous. Primaries with the veins narrowly black marked, the entire surface a little mottled, smoky along the costa, the distinct outwardly anyled smoky median shade forming the most obvious character. There is a slender black basal line. $T$. a. line geminate, the two parts widely separated, black, dentate, distinct only from costa to median vein, the outer part touching the orbicular, a long tooth marking its termination on the inner margin. T. p. line geminate, marked in the costal area only. S. t.line marked by a series of sagittate black spots. There is a series of small black terminal lunules. The median shade is smoky, diffuse, outwardly oblique from costa so as to darken the reniform, then inward so as to reach the inner margin at about its middle. Orbicular round or orate, of good size, a little paler, narrowly outlined by black scales. Reniform large, upright, centrally somewhat constricted, dilated inferiorly, incompletely outlined, darkened by the median shade and by a powdering of rusty scales. Secondaries smoky with a reddish tinge, a little darker outwardly, fringes whitish. Beneath, primaries smoky, with a reddish powdery terminal area and a blackish round discal spot. Secondaries reddish, powdery, with a smoky discal lunule.

Expands 1.75-1.92 inches $=44^{-4} 8 \mathrm{~mm}$.

Habitat: Corvallis, Oregon, September S, at light; British Columbia - no date.

Two males in good condition. The species belongs to the georgii series, differing from them all in the more elongate primaries, the confused mottling, and the very distinct median shade. Incidentally it may be noted that all the species of this series have a black line on the outer side of the hind tibia.

\section{Xylina merceda, n. sp.}

Ground color a deep ashen gray without any reddish admixture. Head and thorax almost mouse gray, a little powdery, collar with an obscure transverse line. Primaries with all the maculation present, not well written, only the paler orbicular standing out in any relief whatever. There is no black line, streak or dash at base. Basal line marked only on costa by geminate blackish lines which tend to become lost. T. a. line geminate, blackish, tending to become lost; irregular, variably outcurved in the interspaces. T. p. line geminate, vague at best, inner line lunulate, almost crenulate, outer a mere shadingrirregular; but as a whole nearly parallel with the outer margin. S. t. line consists of a somewhat irregular dusky shade, more or less broken up into triangular, hardly sagittate spots, outwardly marked by whitish scales. A series of blackish terminal lunules tends to become obsolete. There is a ditfuse, obscure median shade angulated on the renitorm. Claviform very small, loop-like, not always traceable. Orbicular oval, oblique, large, with a submedian annex, paler than the ground and with blackish margins. Reniform large, up. right, a little constricted, margined by black scales within which is a somewhat paler annulus. Secondaries dull whitish or yellowish at base, darkening outwardly to the whitish fringes, markings of underside faintly reproduced. Beneath, primaries smoky, with a powdery pale terminal area: secondaries pale, powdery, with a broad outer shade line and a dark discal lunule. 
Expands $1.44^{-1} \cdot 5^{8}$ inches $=36-39 \mathrm{~mm}$.

Habitat: Cartwright, Manitoba, October 1,6 , November I; Mr. Heath.

Three female specimens, in fair condition, no two alike. In one dark example all the maculation is present as described. in the palest everything is vague and just traceable.

The species is allied to unimoda than which it is smaller, altogether different in ground color, the primaries shorter and broader. From winnipeg it differs yet more in the absence of all the smoky powdering as well as in details of maculation.

BAPTARMA, n. gen.

Head small, closely applied to the thorax, hardly retracted; eyes ovate, moderate in size ; iront broad, protuberant, with a large central depression which is roughened, surrounded by a distinct rim, and has a small central ridge inferiorly; tongue well developed; palpi modcrate, slightly exceeding the frontal protuberance; antennae moderate in length, quite stout. similar in both sexes : vestiture thin divergent hair. Thorax stout, vestiture thin, divergent, hairy, collar and patagia marked but not at all prominent or uplifted; legs short and stout, tibiae not spinose except that there may be either one or two stout curved spines at the outer site of tip on the anterior pair; anterior tarsi with three or four stout curved spines on the basal joint and one each on the second and third joints, making a series of seven or eight stout curved spines on the outer side of the foot between the tip of the tibia and the fourth tarsal joint. Abdomen short, conic, untufted. Primaries small, trigonate, apex drawn out. costa somewhat depressed, outer margin oblique, arquate: secondaries proportionate, venation normal.

The peculiar armature of the fore-legs, combined with the head characters and the absence of other tibial armature should make this easily recognizable.

Baptarma felicita n. sp.

Head, thorax and abdomen black, the vestiture with an admixture of yellow and scarlet hair that gives the effect of a wash or film of these tints. Primaries blackish with a wash of carmine, terminal space a little grayish powdered. There is a small yellow spot at the point in the median cell preceding the reniform; there is a larger, somewhat lunate yellow spot at the point beyond the reniform which would, normally, mark the end of the median space; there is a large, oblong, rectangular blotch in the submedian interspace, occupying what would normally be the outer half of the median space. Secondaries scarlet with a broad black border on all save the costal margin: fringes with a carmine tinge. Beneath, both wings have the disc scarlet, shading to purplish or carmine over the black marginal bands.

Expands $.90-95$ inches $=22-2+\mathrm{mm}$.

Habilat: Yuma County, Arizona, in April ; Mr. Hutson.

One male and one female in good condition and one somewhat defective additional female. The three specimens are very much alike and are readily distinguished by the scarlet secondaries: this scarlet by the bye is variable and less intense in flown examples. So, also, the overlay of purplish or carmine scales on the primaries is apt to be lost, giving the insect a dull smoky, instead of a brilliant purplish tinge. 


\section{Behrensia hutsonii n. sp.}

Ground color white with an admixture of pale brown scales giving it a somewhat smoky or creamy tint. Head and thorax immaculate, the vestiture somewhat loose and divergent. Primaries with all the maculation very distinct, smooth and even, the scales a little lustrous. Basal space whitish, with a light brown powdering, becoming white at the $t$. a. line which is thus emphasized. Basal line black, geminate, distinct, broken. T. a. line begins at costa about one third from base, is inwardly toothed on the median vein, curves outwardly below this and yet on the whole is inwardly oblique, reaching the inner margin well within the basal third. The line is single, black, preceded by a white shade to the inner margin, where it is geminate below vein one. The median space is a very light smoky brown, darkest at the $t$. a. line and lightening somewhat to the $t$. $p$. line which is white, a little diffuse outwardly, starts from costa at about one fourth from apex and runs inwardly oblique, with an incurve in the sub-median interspace, to the internal margin a little beyond the outer third, where it is marked by a black point. The s. t. space is pale smoky brown and darkens outwardly to define the white s. t. line, which forms two even sinuations and reaches the inner margin at the anal angle. Terminal space powdery, more so at the apex, with two or three golden brown spots filling the interspaces at about the middle of the margin. Fringe whitish, marked with dusky at about the middle or the margin. The orbicular is moderate in size, irregular, oblique, narrowly white ringed. Attached to it, below the median vein, is a loop-like accessory spot which is also white ringed and a little darker than the ground. Reniform rather small, narrow, upright, a little constricted, incompletely white-ringed, a little darker inferiorly. Secondaries soiled whitish, a little darker outwardly, fringes white. Beneath, whitish, powdery, maculation of the upper side vaguely reproduced.

Expands $1-1.10$ inches $=25-27 \mathrm{~mm}$.

Habitat: Yuma County, Arizona, in March, Mr. Hutson.

One male and one female, both in good condition save that the antennae are gone. This is a really handsome little species which can hardly be mistaken. It is utterly ditierent in appearance from $\boldsymbol{B}$. conchiformis and may eventually prove a distinct generic type; but from such material as $I$ have at present I prefer to leave matters as above. The female is the larger of the epecimens; otherwise they are much alike. ${ }^{1}$

\section{Erastria panatela n. sp.}

Ground color dull reddish luteous, powdered with rusty red and smoky. Head and thorax as dark as the darkest portion of primaries; without definite maculation. Primaries with all the maculation obscure. The powdery reddish area extends along the inner margin for two thirds from base, then comes a yellowish band which extends obliquely to the apex and in which the black dotted $t$. p. line is in part defined. The terminal space except at apex is again red brown and powdery. There is a series of distinct dusky terminal lunules, of good size. T. a. line obscurely indicated by darker scales and a less powdery included space. Orbicular diffuse, powdery, indefinite, less powdery than the surroundings. Reniform obscure. of good size, partly outlined by black scales, partly marked by the clear ground and further indicated by a darker central shade. Secondaries whitish, soiled, powdery, with a vague

Congeneric with and allied to Autographa albovitta Ottol., which is not an Autographa. 

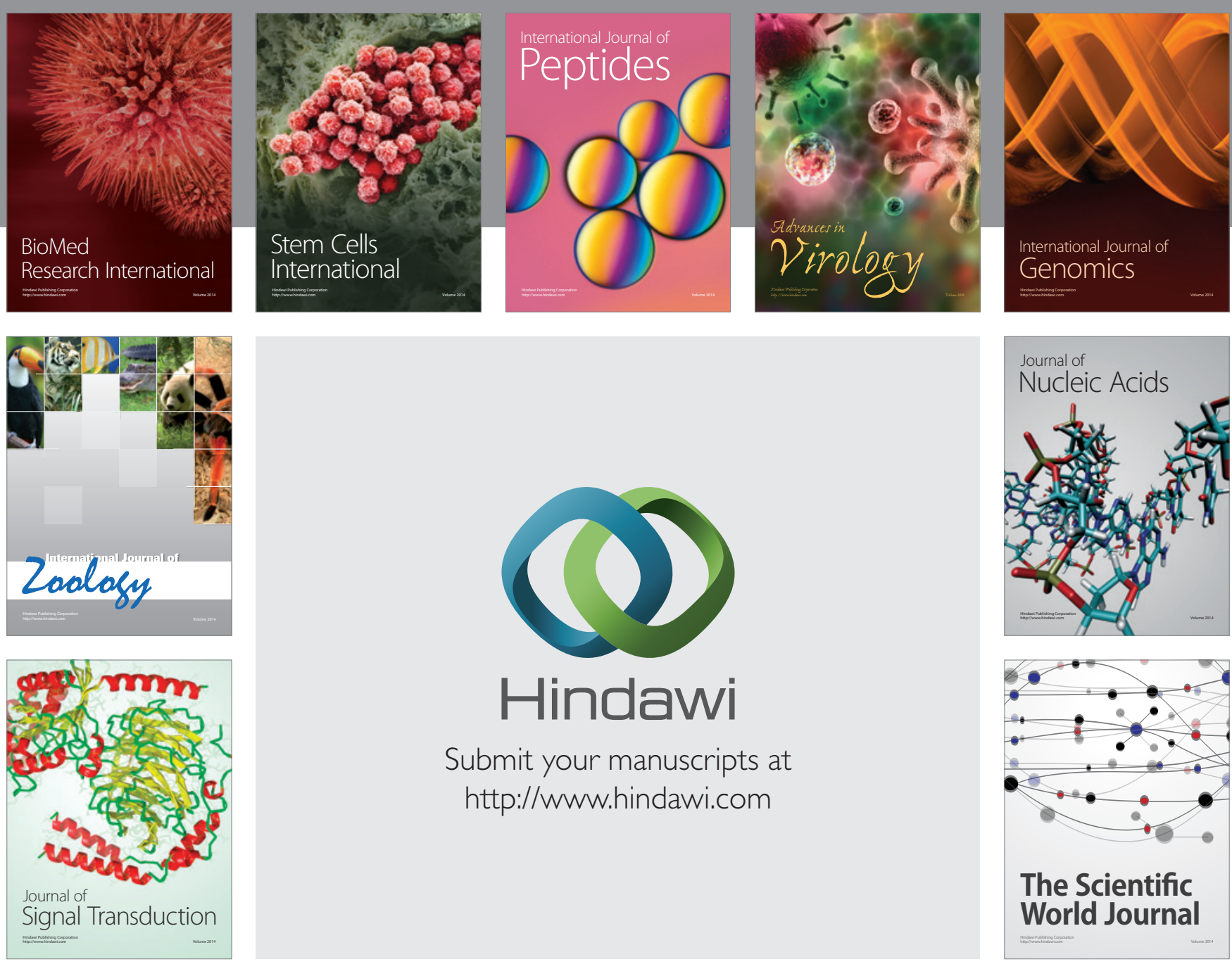

Submit your manuscripts at

http://www.hindawi.com
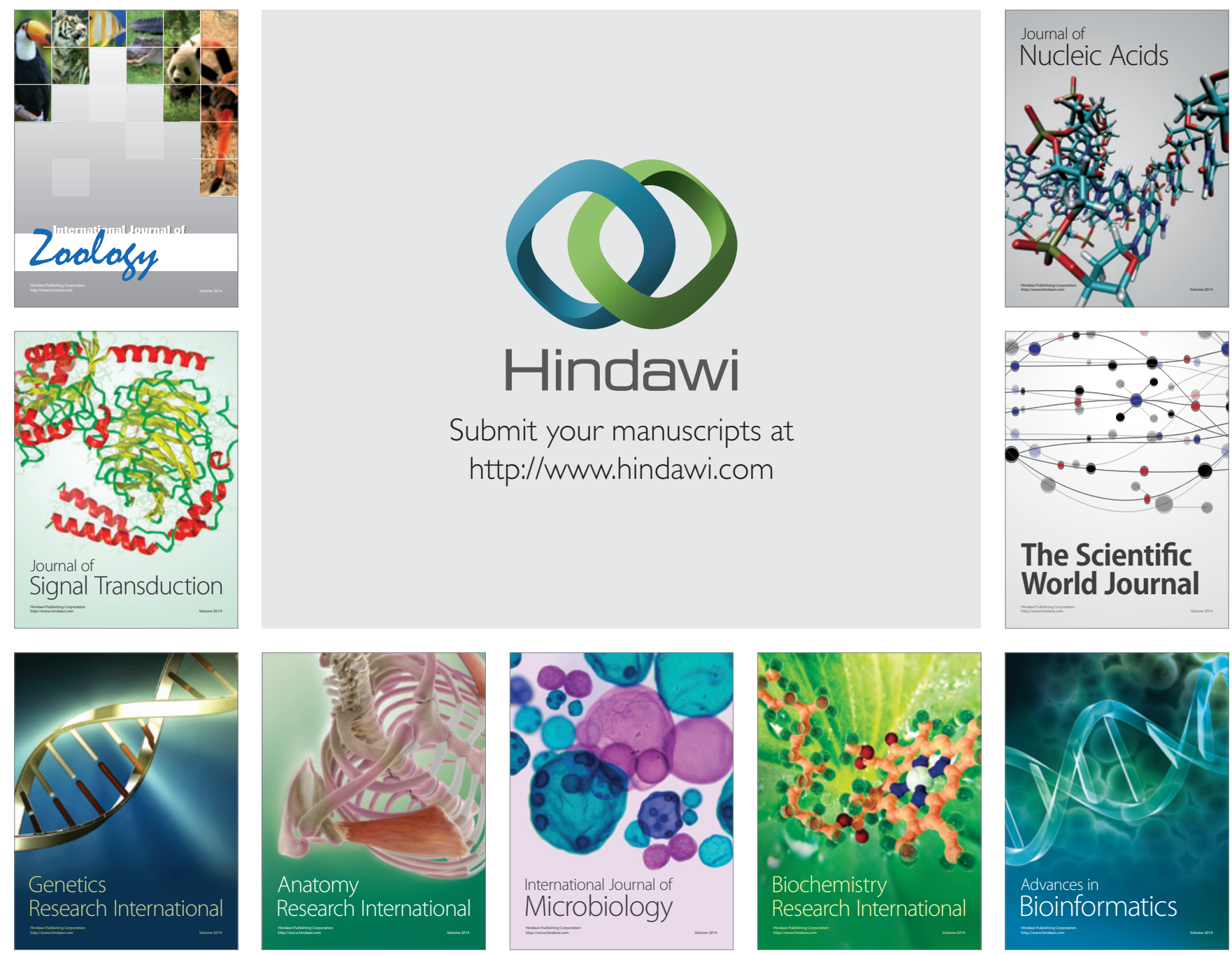

The Scientific World Journal
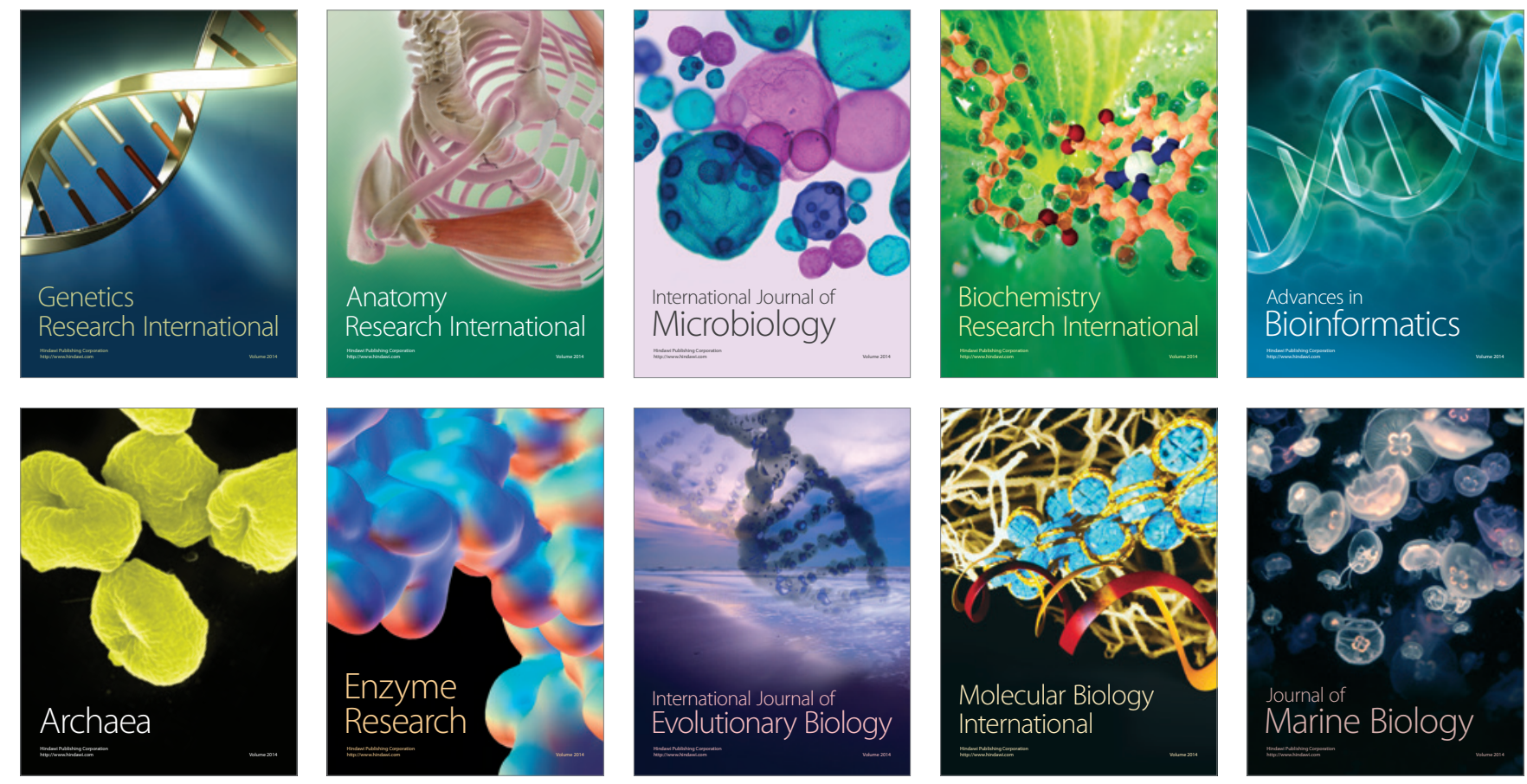